\title{
Site-specific Incorporation of the Mucin-type $N$-Acetylgalactosamine- $\alpha-O$-Threonine into Protein in Escherichia coli
}

\author{
Ran Xu, Sarah R. Hanson, Zhiwen Zhang, Yu-Ying Yang, Peter G. Schultz, * Chi-Huey Wong* \\ Department of Chemistry, The Scripps Research Institute, 10550 Torrey Pines Road, La Jolla, \\ California 92037, USA
}

Materials and methods: All chemicals were purchased from Sigma-Aldrich unless otherwise noted. DNA sequencing was provided by the Protein and Nucleic Acids Core Facility at the Scripps Research Institute. Mass spectral analysis was carried out by the Scripps Center for Mass Spectrometry, Professor Joseph A. Loo (University of California, Los Angeles), and Professor Yu-Ju Chen (Academia Sinica, Taiwan).

Chemical synthesis of GalNAc- $\alpha$-Threonine (2): The synthetic route was constructed according to published methods, ${ }^{[1]}$ with some modifications as depicted (Scheme S1):
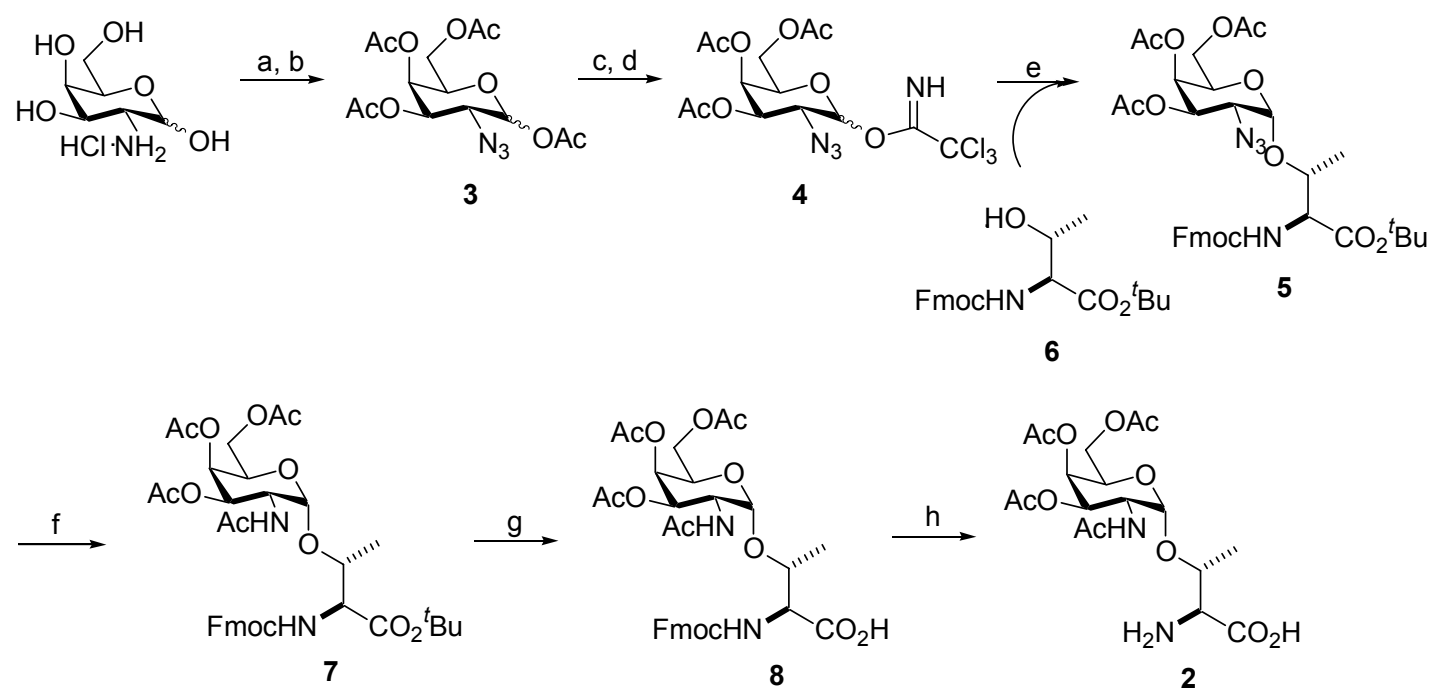

Scheme S1. Synthesis of GalNAc- $\alpha$-threonine (2): (a) $\mathrm{TfN}_{3}, \mathrm{~K}_{2} \mathrm{CO}_{3}, \mathrm{CuSO}_{4}, \mathrm{CH}_{2} \mathrm{Cl}_{2}, \mathrm{MeOH}, \mathrm{H}_{2} \mathrm{O}$; (b) $\mathrm{Ac}_{2} \mathrm{O}$, pyridine; (c) hydrazine acetate, DMF; (d) trichloroacetonitrile, $\mathrm{K}_{2} \mathrm{CO}_{3}, \mathrm{CH}_{2} \mathrm{Cl}_{2}$; (e) 4, TMSOTf, $\mathrm{CH}_{2} \mathrm{Cl}_{2}, \mathrm{Et}_{2} \mathrm{O},-30{ }^{\circ} \mathrm{C}, \alpha / \beta=4 / 1(57 \%, 5$ steps); (f) $\mathrm{Zn} / \mathrm{Cu}, \mathrm{Ac}_{2} \mathrm{O}$, AcOH, THF; (g) $95 \% \mathrm{CF}_{3} \mathrm{COOH}$ in $\mathrm{H}_{2} \mathrm{O}$ (74\%, 2 steps); (h) $20 \%$ piperidine in DMF.

NMR spectroscopic data of 2 was obtained using a Bruker DRX-600: ${ }^{1} \mathrm{H}$ NMR $\left(600 \mathrm{MHz}, \mathrm{D}_{2} \mathrm{O}\right) \delta$ 1.45 (d, $J=7.0 \mathrm{~Hz}, 3 \mathrm{H}), 2.02$ (s, 3H), 2.04 (s, 3H), 2.10 (s, 3H), 2.22 (s, 3H), 3.78 (brs, 1H), 4.18-4.25 (m, $2 \mathrm{H}), 4.42(\mathrm{dd}, J=10.9,3.5 \mathrm{~Hz}, 1 \mathrm{H}), 4.49-4.50(\mathrm{~m}, 2 \mathrm{H}), 5.10(\mathrm{~d}, 3.5 \mathrm{~Hz}, 1 \mathrm{H}), 5.19$ (dd, $J=11.4,2.6$ $\mathrm{Hz}, 1 \mathrm{H}), 5.45$ (brs, $1 \mathrm{H}) ;{ }^{13} \mathrm{C}$ NMR $\left(125 \mathrm{MHz}, \mathrm{D}_{2} \mathrm{O}\right) \delta 20.90,20.91,20.97,48.49,59.86,63.44,67.99$, 68.92, 69.56, 76.37, 100.22, 172.53, 173.89, 174.21, 174.38, 175.27; MALDI-FTMS of 2 was acquired on an IonSpec FTMS mass spectrometer: $m / z$ $471.1586\left(\mathrm{C}_{18} \mathrm{H}_{28} \mathrm{~N}_{2} \mathrm{O}_{11} \mathrm{Na},[\mathrm{M}+\mathrm{Na}]^{+}\right.$calculated 471.1585). 
Directed evolution of MjTyrRS: For the first round of positive screening, competent E. coli DH10 $\beta$ cells containing plasmid $\mathrm{pREP} / \mathrm{YC}-\mathrm{JYCUA}^{[2]}$ were transformed with a combination of two libraries: pBK-lib-m, with residues Tyr32, Ala67, His70, Gln155, Asp158, and Ala167 randomized, and pBK-lib, with residues Tyr32, Glu107, Asp158, Ile159, and Leu162 randomized. The combined library had approximately $2.6 \times 10^{9}$ independent clones. The transformed cells were grown at $37{ }^{\circ} \mathrm{C}$ in $500 \mathrm{~mL}$ of glycerol minimal medium with leucine (GMML, $1 \times \mathrm{M} 9$ minimal medium, $1 \%$ glycerol, $1 \mathrm{mM} \mathrm{MgCl}_{2}$, $0.1 \mathrm{mM} \mathrm{CaCl} 2,0.5 \% \mathrm{NaCl}$, and $0.3 \mathrm{mM}$ leucine) containing $50 \mu \mathrm{g} / \mathrm{mL}$ kanamycin, $24 \mu \mathrm{g} / \mathrm{mL}$ tetracycline, $68 \mu \mathrm{g} / \mathrm{mL}$ chloramphenicol, and $1 \mathrm{mM}$ of 2 . After $60 \mathrm{~h}$, the plasmids were extracted from the surviving cells and transformed into DH10 $\beta$ containing plasmid pLWJ17B3. ${ }^{[3]}$ The transformants were then spread on Luria-Bertani plates containing $50 \mu \mathrm{g} / \mathrm{mL}$ kanamycin, $68 \mu \mathrm{g} / \mathrm{mL}$ chloramphenicol, and $0.02 \% \mathrm{~L}$-arabinose and incubated at $37{ }^{\circ} \mathrm{C}$ for $10 \mathrm{~h}$. The surviving cells were collected, and the plasmids were purified for the next round of positive screening. In total, four rounds positive and three rounds of negative screening were carried out alternatively to yield four clones of MjTyrRS mutants that showed increased chloramphenicol resistance in the presence of $\mathbf{2}$. The isolated mutants also exhibited higher expression levels of GFPuv when grown in the presence of glycosyl amino acid $2(+)$ than without it (-), as indicated by emitted fluorescence from the cell colonies (Figure S1). Mutations of the evolved mutants are listed in Table S1.

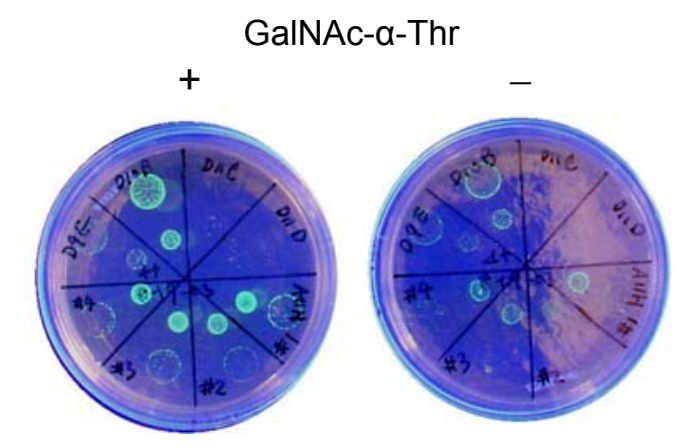

Figure S1. Isolated MjTyrRS mutants allowed better expression of GFPuv gene in positive selection by amber codon suppression.

Table S1. Mutations of evolved MjTyrRS that accept glycosyl amino acids

\begin{tabular}{|c|c|c|c|c|c|c|}
\hline MjTyrRS & Wild-type & $\mathrm{I}-90$ & $\mathrm{AH} 1$ & $\mathrm{C} 8 \mathrm{~F}$ & $\mathrm{C} 10 \mathrm{~F}$ & $\mathrm{D} 10 \mathrm{~B}$ \\
\hline $\begin{array}{l}\text { Tyr-binding } \\
\text { residues** }\end{array}$ & $\begin{array}{l}\text { Tyr32* } \\
\text { His70* } \\
\text { Tyr151 } \\
\text { Gln155* } \\
\text { Asp158* } \\
\text { Gln173 }\end{array}$ & Cys & Phe & Gln & $\begin{array}{l}\text { Ala } \\
\text { Pro }\end{array}$ & $\begin{array}{l}\text { Leu } \\
\text { Lys } \\
\text { Ser } \\
\text { Val }\end{array}$ \\
\hline Other residues & $\begin{array}{l}\text { Ala } 67^{*} \\
\text { Leu98 } \\
\text { Glu107* } \\
\text { Val149 } \\
\text { Ile159 } \\
\text { Leu162* } \\
\text { Gly163 } \\
\text { Ala167* }\end{array}$ & $\begin{array}{l}\text { Pro } \\
\text { Tyr } \\
\text { Arg }\end{array}$ & Pro & Pro & $\begin{array}{l}\text { Ser } \\
\text { lle }\end{array}$ & $\begin{array}{l}\text { Thr } \\
\text { Ile }\end{array}$ \\
\hline Total mutations & & 4 & 2 & 4 & 4 & 7 \\
\hline
\end{tabular}


Protein expression, purification and characterization: The mutant myoglobin (Gly4 mutated to amber codon TAG), MjTyrRS mutants (AH1 and C10F, independently), and mutant Tyr-tRNA ${ }_{\mathrm{CUA}}$ genes were co-expressed in DH10 $\beta$. The culture was grown in $500 \mathrm{~mL}$ of GMML with $50 \mu \mathrm{g} / \mathrm{mL}$ kanamycin, 24 $\mu \mathrm{g} / \mathrm{mL}$ tetracycline, and $1 \mathrm{mM}$ of 2 until $\mathrm{OD}_{600}$ reached 0.6 . Protein expression was then induced by adding L-arabinose to a final concentration of $0.02 \%$ followed by $8 \mathrm{~h}$ of growth at $30{ }^{\circ} \mathrm{C}$ with aeration. Cells were harvested and lysed, and the proteins were purified using $\mathrm{Ni}^{2+}$-NTA affinity chromatography under native conditions (Qiagen Inc., Valencia, CA). Proteins were analyzed by 10\% NuPAGE BisTris Gel and stained with SimplyBlue Safestain (Invitrogen, Carlsbad, CA). The molecular weight of the obtained protein products were analyzed by coupled reverse-phase liquid chromatography electrospray ionization time-of-flight (LC ESI-TOF) mass spectrometry.

Enzyme-linked lectin-binding assay (ELLA). The GalNAc- $\alpha-T h r$ specific lectins, Vicia Villosa lectin (VVL) and Dolichos Biflorus (DBL) were purchased as biotinylated conjugates from Vector Laboratories (Burlingame, CA). Purified myoglobin samples were aliquoted (600 ng) into high-binding microtiter pates (Maxisorp, Nunc). The plate was blocked in PBS containing 3\% BSA and then treated with lectin $(10 \mu \mathrm{g} / \mathrm{mL}$ in PBS). After three PBS washes, alkaline phosphatase conjugated to streptavidin (AP-St, Roche) was added to each well (1 U/mL in PBS). Following lectin treatment, the plate was washed three times before the AP substrate, $p$-nitrophenol phosphate (pNPP) was added $(1 \mathrm{mg} / \mathrm{mL}$ $\mathrm{pNPP}$ in $10 \mathrm{mM}$ diethanolamine buffer, $\mathrm{pH} 9.5$, containing $0.5 \mathrm{mM} \mathrm{MgCl}_{2}$ ). AP activity was monitored at $405 \mathrm{~nm}$. As depicted in Figure S2, an increased signal was detected between myoglobin samples grown with GalNAc- $\alpha$-Thr and without.
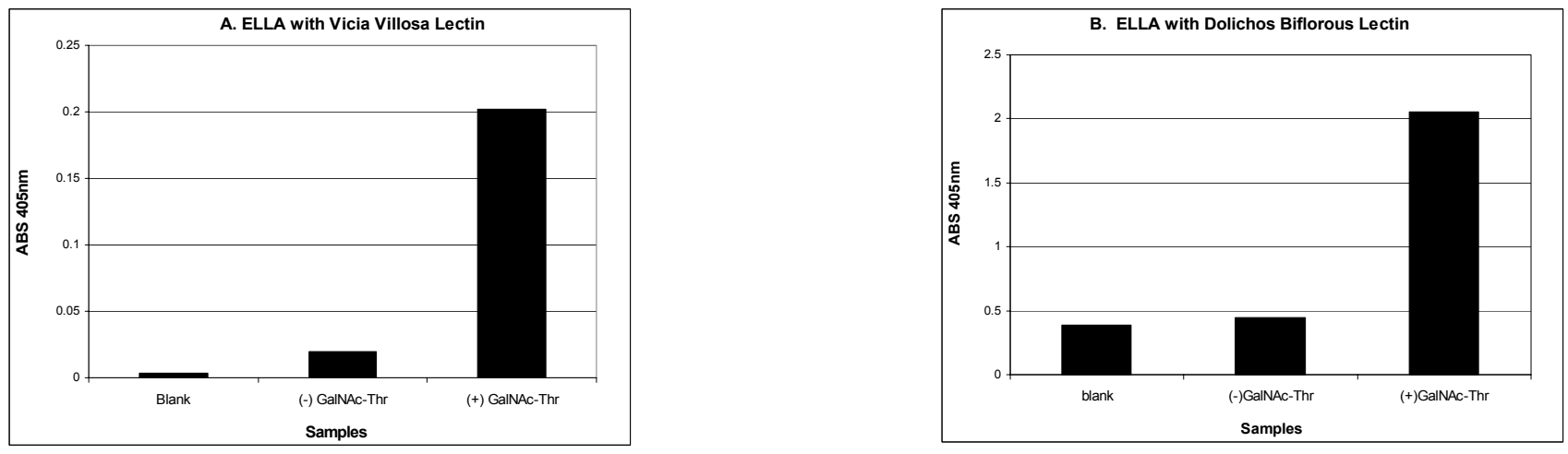

Figure S2. The GalNAc-specific lectins VVL (A) and DBL (B) were used to probe glycomyoglobin samples. A 10- and 5fold increase in ELLA signal, with VVL and DBL, respectively, was observed for myoglobin samples expressed with GalNAc- $\alpha-T h r(+)$ versus those grown without glycosyl amino acid $(-)$. Blank samples composed of pNPP substrate without any AP-St, represent background hydrolysis.

\section{References}

[1] Grundler, G.; Schmidt, R. R. Liebigs Annalen der Chemie 1984, 1826-1847.

[2] Santoro, S. W.; Wang, L.; Herberich, B.; King, D. S.; Schultz, P. G. Nat. Biotechnol. 2002, 20, $1044-1048$.

[3] Wang, L.; Schultz, P. G. Chem. Biol. 2001, 8, 883-890.

[4] Kobayashi, T.; Nureki, O.; Ishitani, R.; Yaremchuk, A.; Tukalo, M.; Cusack, S.; Sakamoto, K.; Yokoyama, S. Nat. Struct. Biol. 2003, 10, 425-432 